\title{
Alternate antigen processing in the presence of gamma interferon may misdirect the immune recognition of cancer
}

\author{
Katherine Woods ${ }^{*}$, Ralf B Schittenhelm², Dani Heesterbeek', Ashley Knights ${ }^{1}$, Matthew Anaka', \\ Anthony W Purcell ${ }^{2}$, Andreas Behren ${ }^{1}$, Jonathan Cebon ${ }^{3}$ \\ From 30th Annual Meeting and Associated Programs of the Society for Immunotherapy of Cancer (SITC 2015) \\ National Harbor, MD, USA. 4-8 November 2015
}

Degradation of cellular proteins by the proteasome is critical for the generation of $\mathrm{MHC}$-associated peptides. The constitutive proteasome and the IFN $\gamma$-induced immunoproteasome (IP) differ in the use of three catalytic $\beta$ subunits, which alters production of MHC class I epitopes. The potential for a disparate repertoire of epitopes produced between inflammatory/non-inflammatory tumours therefore arises.

We have extensively investigated this phenomenon both broadly, in terms of the cancer cell as a whole, and specifically, by evaluating presentation of three NY-ESO-1 HLACw3 restricted epitopes.

We profiled the immunopeptidome of a melanoma cell line under steady state or IFN $\gamma$-treated conditions; by mass spectrometry analysis of HLA Class I bound peptides. Profound changes in the overall epitope profile presented on HLA Class I molecules, leading to extensive alteration in the overall immunogenicity of the cell, were observed.

We studied processing and presentation of three NYESO-1 HLA-Cw3 restricted epitopes by melanoma cell lines. Using specific T-lymphocyte clones, we examined presentation of each epitope following processing through proteasome subtypes. We further investigated processing of these epitopes by selective inhibition of the IP catalytic subunit LMP7 by siRNA knockdown, or small molecule inhibition.

In vivo, we demonstrate that melanoma cells can be induced to switch proteasome subtype following treatments which induce IFN $\gamma$ at the tumour site.

${ }^{1}$ Olivia Newton-John Cancer Research Institute, Melbourne, Australia Full list of author information is available at the end of the article
Our data demonstrate broad changes in epitopes presented by melanoma cells under inflammatory versus non-inflammatory conditions. These results illustrate a little-studied mechanism of immune escape by tumour cells. Awareness of how individual cancer epitopes are processed by melanoma cells is therefore critical to inform development of future therapies which involve cancer vaccination, adoptive T-lymphocyte transfer, or combination treatments including these.

\section{Authors' details \\ 'Olivia Newton-John Cancer Research Institute, Melbourne, Australia. ${ }^{2}$ Monash University, Melbourne, Australia. ${ }^{3}$ Olivia Newton-John Cancer Research Institute, Heidelberg, Australia.}

Published: 4 November 2015

doi:10.1186/2051-1426-3-S2-P453

Cite this article as: Woods et al:: Alternate antigen processing in the presence of gamma interferon may misdirect the immune recognition of cancer. Journal for ImmunoTherapy of Cancer 2015 3(Suppl 2):P453.

Submit your next manuscript to BioMed Central and take full advantage of:

- Convenient online submission

- Thorough peer review

- No space constraints or color figure charges

- Immediate publication on acceptance

- Inclusion in PubMed, CAS, Scopus and Google Scholar

- Research which is freely available for redistribution 